\title{
PENGARUH KOMPETENSI PROFESIONAL GURU TERHADAP MOTIVASI BELAJAR SISWA
}

\author{
Zul Andi Kurniadi), irina popoi ${ }^{2}$, melizubaida mahmud ${ }^{3)}$ \\ Universitas Negeri Gorontalo, \\ Email: Kurniadi@gmail.com
}

\begin{abstract}
ABSTRAK
Penelitian ini bertujuan untuk mengetahui seberapa besar pengaruh kompetensi profesional guru terhadap motivasi belajar siswa kelas VIII pada mata pelajaran IPS Terpadu di SMP Negeri 2 Telaga Kabupaten Gorontalo.Metode yang digunakan dalam penelitian ini adalah metode kuantitatif deskriptif. Sampel dalam penelitian ini berjumlah 29 responden. Adapun teknik analisis data yang digunakan yaitu analisis regresi. Hasil penelitian ini menyimpulkan bahwa kompetensi profesional guru memiliki pengaruh positif dan signifikan terhadap motivasi belajar siswa kelas VIII pada mata pelajaran IPS terpadu di SMP Negeri 2 Telaga Kabupaten Gorontalo. Ini terlihat dari hasil analisis regresi dimana kompetensi profesional guru berpengaruh terhadap motivasi belajar siswa yang mencapai $36,7 \%$ dan sisanya $63,3 \%$ dipengaruhi oleh variabel lain.
\end{abstract}

Kata kunci : Kompetensi Profesional Guru, Motivasi Belajar Siswa

\begin{abstract}
This study aims to learn more about the professional competence of teachers on class VIII student motivation in Integrated Social Sciences subjects at SMP Negeri 2 Telaga, Gorontal District. The method used in this study is descriptive quantitative method. The sample in this study was an experimental 29 respondents. The data analysis technique used is regression analysis. The results of this study prove that professional competence has a positive and significant effect on student motivation in class VIII on Integrated Social Sciences subjects at SMP Negeri 2 Telaga, Gorontalo Regency. This can be seen from the results of the regression analysis while the professional competence that is intended for student motivation reaches $36.7 \%$ and the remaining $63.3 \%$ is needed by other variables.
\end{abstract}

Keywords: Teacher Professional Competence, Student Learning Motivation 


\section{PENDAHULUAN}

Motivasi belajar adalah hal yang sangat penting dan tidak bisa dipisahkan dari dunia pendidikan. Dengan motivasi belajar dalam kegiatan pembelajaran dapat menjadi tenaga pendorong untuk siswa dapat lebih semangat dalam proses pembelajaran dan bisa mendayagunakan pola berfikir kritis dalam pengetahuan siswa.

Motivasi belajar perlu dimiliki oleh siswa, karena dengan memiliki motivasi belajar siswa dapat memperoleh hasil yang baik dan dapat berkembang secara maksimal. Motivasi belajar juga bertujuan untuk menjadikan siswa memiliki pribadi yang baik dan berkualitas sehingga mampu untuk berfikir secara positif.

Siswa yang mempunyai motivasi belajar memiliki kesungguhan untuk terlibat dalam kegiatan pembelajaran seperti aktif dalam bertanya,mengemukkan argumentasi atau pendapat mengenai materi pembelajaran, rajin menulis catatancatatan penting yang dikatakan oleh guru, serta menyimak isi materi yang sedang berlangsung dan mampu mempraktikkan sesuatu yang positif sesuai dengan yang guru ajarkan.

Motivasi belajar yang ada pada diri siswa juga harus membutuhkan dukungan dari berbagai pihak, contohnya yang paling dekat adalah dukungan dari pihak keluarga. Dimana keadaan keluarga yang kondusif yang mampu memberikan kasih sayang, perhatian yang harmonis dalamMotivasi belajar merupakan hal yang menyebabkan seseorang memiliki keinginan untuk melakukan sesuatu. Motivasi belajar dapat membuat peserta didik memiliki keinginan untuk belajar. Siswa yang memiliki motivasi belajar yang tinggi akan lebih bersungguh-sungguh dalam belajar.

Motivasi disini adalah kekuatan yang ada dalam diri seseorang yang ditandai dengan munculnya perasaan untuk melakukan kegiatan tertentu untuk mencapai tujuannya. Motivasi belajar merupakan salah satu faktor yang turut menentukan keefektifan dalam pembelajaran. Seorang peserta didik belajar dengan baik apabila ada faktor pendorongnya yaitu motivasi belajar. Peserta didik akan belajar dengan sungguh-sungguh jika memiliki motivasi belajar yang tinggi.

Motivasi yang timbul dari peserta didik merupakan motivasi intrinsik. Atau dari dalam diri sendiri Motivasi intrinsik berpengaruh terhadap kelangsungan proses belajar peserta didik. Seseorang yang termotivasi dengan baik dalam belajar akan melakukan kegiatan lebih banyak dan lebih cepat, dibandingkan dengan siswa yang kurang termotivasi dalam belajar. Prestasi yang diraih akan lebih baik apabila mempunyai motivasi yang tinggi.

Motivasi belajar merupakan salah satu faktor yang diduga besar pengaruhnya terhadap hasil belajar. Siswa yang motivasinya tinggi akan memperoleh hasil belajar yang baik. Pentingnya motivasi belajar siswa terbentuk antara lain agar terjadi perubahan belajar kearah yang lebih postitif 
Keluaraga serta Situasi ekonomi keluarga yang memadai untuk kebutuhan anak disekolah. Motivasi belajar yang ditanamkan pada anak oleh orang tua sangatlah penting untuk anak dapat memiliki semangat dalam belajar dan mengikuti pelajaran disekolah.

Faktor lain yang mempengaruhi motivasi belajar adalah lingkungan bermain anak atau siswa, jika lingkungan bermain memiliki situasi yang baik maka motivasi belajar juga akan baik. Seperti, anak-anak aktif dalam berkomunikasi sesame teman sebaya, serta faktor-faktor lain yang mendukung sehingga anak dapat termotivasi untuk belajar demi meraih tujuan dan cita-cita yang mereka inginkan.

Motivasi adalah hal yang menyebabkan seorang anak atau siswa memiliki keinginan untuk melakukan sesuatu. Motivasi belajar dapat membuat siswa memiliki keinginan untuk belajar. Siswa yang memiliki motivasi belajar yang tinggi akan lebih bersungguh-sungguh dalam belajar.

Motivasi Belajar Siswa ditandai dengan adanya keinginan siswa untuk berhasil, adanya cita-cita masa depan yang ingin dicapai oleh siswa, perilaku yang tekun menghadapi tugas, menunjukkan minat pada berbagai macam masalah, senang bekerja mandiri, tidak cepat bosan pada tugas-tugas rutin, dan dapat mempertahankan pendapat dalam diskusi dan dapat menghasilkan prestasi yang baik.

Demi mencapai harapan diatas pendidikan membutuhkan yang namanya tenaga pendidik atau guru yang professional. Maka guru yang memiliki profesionalitas yang tinggi dibutuhkan untuk menghadapi situasi mengenai motivasi belajar. Guru harus mampu mendorong siswa agar siswa mau belajar dan termotivasi untuk meraih cita-cita yang diinginkan.

Secara garis besar guru adalah faktor penentu tingi rendahnya kualitas pendidikan. Guru juga memegang peran penting dan utama dalam pembangunan pendidikan yang ada disekolah. Guru adalah kunci dalam peningkatan mutu pendidikan, mutu pendidikan yang ada pada sekolah tidak akan berarti jika tidak disertai dengan guru professional.

Dalam Pasal 28 ayat 3 Peraturan pemerintah nomor 19 tahun 2005 tentang Standar Nasional pendidikan bahwa" kompetensi ageb pembelajaran pada jenjang pendidikan dasar dan menengah serta pendidikan anak usia dini meliputi a.kompetensi pedagogik, b. kompetensi kepribadian, c. kompetensi professional,d. kompetensi sosial".

Kompetensi professional guru menurut pasal 10 UU No. 12 Tahun 2005 adalah kemampuan penguasaan materi pembelajaran secara luas dan mendalam. Artinya bahwa seorang guru harus memiliki pendalaman atau penguasaan materi menurut bidang studi yang telah dimiliki untuk tercapainya tujuan pembelajaran secara optimal

Guru yang professional bukan hanya mempu untuk memotivasi siswa dalam hal belajar, tetapi juga harus mempu memberikan solusi terhadap siswa yang memiliki masalah yang kompleks, baik masalah keluarga maupun masyarakat. 
Guru juga harus mampu menjadi tauladan bagi peserta didik dan menanamkan nilai-nilai norma yang ada pada lingkungan masyarakat.

Hubungan guru yang baik dalam proses pembelajaran akan member pengaruh motivasi belajar siswa. Gru juga harus member relasi yang baik kepada siswa. Contohnya, guru memberikan perhatian dengan menyapa siswa, mampu menanggapi kebutuhan siswa dalam belajar, memiliki ketulusan hari dalam membantu siswa jika ada kesulitan.

Alat pembelajaran atau sarana dan prasarana menjadi faktor pnedukung siswa dalam belajar.contohnya seperti media pembelajaran yang digunakan oleh guru saat mengajar, ruang kelas yang bersih dan nyaman. Faktor lain adalah mengenai penggunaan metode pembelajaran yang digunakan oleh guru harus baik contohnya seperti memilih cara belajar yang tepat dan waktu istirahat yang cukup agar siswa tidak bosan dalm kegiatan belajar.

Pada observasi awal yang terjadi saat ini di SMP NEGERI 2 TELAGA siswa kurang termotivasi belajar dikarenakan guru saat mengajar dalam penggunaan media pembelajaran kurang maksimal. Akibatnya siswa banyak yang bosan untuk belajar khususnya mata pelajaran IPS Tepadu, siswa juga banyak yang keluar kelas saat proses pembelajaran dengan alasan ke toilet padahal hanya duduk di kantin.

Bukan hanya itu saja ketika proses pembelajaran juga siswa diberi kesempatan untuk memberikan pertanyaan tetapi siswa tidak ada yang ingin memberikan pertanyaan dan saat diberikan tugas untuk dikerjakan dirumah siswa juga malas untuk mengerjakan tugas tersebut. Motivasi belajar memang sangat penting untuk seorang siswa dalam proses pembelajaran demi tercapainya pendidikan yang berkualitas dan bermutu tinggi.

\section{II.METODE PENELITIAN}

Penelitian ini menggunakan metode kuantitatif deskriptif, Metode deskriptif merupakan metode penelitian yang digunakan untuk menggambarkan masalah yang terjadi pada masa sekarang atau yang sedang berlangsung, bertujuan untuk mendeskripsikan apa-apa yang terjadi sebagaimana mestinya pada saat penelitian dilakukan (Sugiyono, 2017:207). Metode ini bertujuan memberikan dipelajari dan kemudian ditarik kesimpulannya (Sugiyono. 2017: 117). Berdasarkan penelitian tersebut, maka yang menjadi populasi dalam penelitian ini adalah seluruh siswa kelas VIII sebanyak 219 siswa. gambaran tentang pengaruh signifikan tentang Pengaruh Kompetensi Profesional Guru Terhadap Motivasi Belajar Siswa Kelas VIII Pada Mata Pelajaran IPS Terpadu Di SMP Negeri 2 Telaga. Variabel bebas penelitian adalah kompetensi profesional. Variabel terikatnya adalah motivasi belajar.

Populasi adalah wilayah generalisasi yang terdiri atas obyek/subyek yang mempunyai kualitas dan karakteristik tertentu yang ditetapkan oleh peneliti untuk 
Sugiyono (2012) sampel adalah bagian dari jumlah dan karakter yang dimiliki ole populasi tersebut. Bila populasi besar, maka peneliti tidak mungkin mempelajari semua yang ada pada populasi.Apabila subjek yang diteliti kurang dari 100, maka lebih baik di ambil semuanya sehingga penelitiannya merupakan penelitian populasi. Tetapi apabila jumlah subjeknya besar, dapat diambil 10-15\% atau $20-25 \%$.

Berdasarkan hal tersebut di atas, maka yang menjadi sampel penelitian ini adalah 15\% dengan jumlah 33 responden.

Teknik pengumpulan data yang digunakan adalah angket, dokumentasi dan observasi. Sedangkan teknik pengujian menggunakan uji validtitas dan reliabilitas, normalitas dan regresi.

A. Uji Validitas dan Reliabilitas

1. Uji Validitas

Teknik yang digunakan untuk mengetahui kesejajaran adalah teknik product moment angka kasar yang dikemukakan oleh person.

$$
r_{x y} \frac{N \Sigma x y-(\Sigma x)(\Sigma y)}{\sqrt{\left\{N \Sigma x^{2}-(\Sigma x)^{2}\right\}\left\{N \Sigma y^{2}-(\Sigma y)^{2}\right\}}}
$$

Dimana

(Sugiyono, 2015:255)

$r_{x y} \quad$ : koefisien korelasi antara skor item dan skor total tiap item

$\Sigma \mathrm{x} \quad$ : jumlah skor tiap-tiap item

$\Sigma y \quad$ : jumlah skor total item

$\mathrm{N} \quad$ : jumlah responden uji coba angket

$\Sigma x^{2} \quad$ : jumlah kuadrat skor tiap-tiap item

$\Sigma y^{2} \quad$ : jumlah kuadrat skor total tiap responden

$\Sigma x y \quad$ : jumlah perkalian skor tiap item dan skor total tiap-tiap responden

2. Uji Reliabilitas

Sugiyono (2017 : 173) menjelaskan instrumen yang reliabel adalah instrumen yang bila digunakan beberapa kali untuk mengukur objek yang sama, akan menghasilkan data yang sama. Perhitungan reliabilitas instrumen menggunakan rumus korelasi alpha cronbach, yaitu:

$$
r_{\mathrm{r} 11}=\left[\frac{K}{K-1}\right]\left[\frac{\Sigma Q_{i^{2}}}{Q_{i^{2}}}\right]
$$

(Sugiyono, 2015:187)

Dimana

$r_{11}=$ reliabilitas instrumen

$\mathrm{K} \quad$ = banyaknya butir pertanyaan atau banyaknya soal

$\Sigma Q_{i^{2}}=$ jumlah varians butir

$Q_{i^{2}} \quad=$ varians total

B. Uji Normalitas Pengujian normalitas 
dapat dimaksudkan untuk mengetahui apakah data hasil penelitian berasal dari populasi yang berdistribusi normal atau tidak. Untuk kepentingan normalitas data dapat digunakan rumus sebagai berikut:

$$
\left(X^{2}\right)=\sum \frac{(f o-f e)^{2}}{f e}
$$

(Sugiyono, 2015:241)

Keterangan:

$X^{2}=$ Chi Kuadrat

fo = hasil pengamatan

$f e \quad=$ jumlah/frekuensi yang diharapkan

C. Teknik Analisis Data

Teknik analisis data yang digunakan adalah regresi linear sederhana. Persamaan umum regresi linear sederhana adalah:

$$
\hat{\mathrm{Y}}=\alpha+b X
$$

(Sugiyono, 2015:262)

Dimana:

$\hat{\mathrm{Y}} \quad=$ subjek dalam variabel terkait yang diprediksikan

$\alpha=$ konstanta atau bila harga $\mathrm{X}=0$

$b=$ koefisien regresi atau angka arah yang menunjukkan angka arah yang menunjukkan angka peningkatan ataupun penurunan variabel dependen yang didasarkan pada perubahan variabel independen.

$X \quad=$ subyek pada variabel independen yang mempunyai nilai tertentu.

Harga a dan $\mathrm{b}$ melalui dengan rumus sebagai berikut:

$$
\begin{gathered}
\alpha=\frac{(\Sigma \hat{Y})\left(\Sigma x^{2}\right)-(\Sigma \hat{Y})(\Sigma x \hat{Y})}{n \Sigma x^{2}-(\Sigma x)^{2}} \\
b=\frac{n(\Sigma x \hat{Y})-(\Sigma x)(\Sigma \hat{Y})}{n \Sigma x^{2}-(\Sigma x)^{2}}
\end{gathered}
$$

(Sugiyono, 2015:262)

\section{III.HASIL DAN PEMBAHASAN}

\section{Hasil Pengujian Validitas dan Reliabilitas Kuesioner}

Hasil analisis menunjukkan bahwa dari segi ketepatan dalam mengukur dari 15 pertanyaan yang digunakan dalam mengukur kompetensi profesional. Seluruh pertanyaan telah memiliki ketepatan yang baik. adapun hasil pengujian validitas untuk variabel kompetensi profesional adalah sebagai berikut:

\begin{tabular}{r|cr}
\hline \multicolumn{2}{c}{ Reliability Statistics } \\
\hline Cronbach's Alpha & N of Items \\
& & 15 \\
\hline
\end{tabular}


Nilai koefisien reliabilitas untuk variabel koleksi buku dari hasil diatas adalah sebesar 0,814. Adapun untuk reliabilitas pertanyaan yang digunakan, seluruh pertanyaan yang digunakan telah memenuhi syarat reliabilitas yakni di atas 0,6. Dengan demikian dapat disimpulkan bahwa pertanyaan-pertanyaan yang digunakan telah dapat dipahami baik oleh responden dan mampu menunjukkan konsistensi jawaban yang cukup baik pula.

Pengujian Normalitas Data

Tabel 1. Hasil Uji Normalitas Data

\begin{tabular}{l|r}
\hline \multicolumn{2}{c}{ One-Sample Kolmogorov-Smirnov Test } \\
\hline $\mathrm{N}$ & \multicolumn{2}{|c}{$\begin{array}{c}\text { Unstandardized } \\
\text { Residual }\end{array}$} \\
\hline Kolmogorov-Smirnov Z & 29 \\
\hline Asymp. Sig. (2-tailed) &, 096 \\
\hline
\end{tabular}

Berdasarkan hasil pengujian normalits pada table di atas, diperoleh hasil Kolmogorov-Smirnov Z sebesar 0,096 dengan nilai asymp. Sig. (2-tailed) atau probabilitas sebesar 0,2 yang berada di atas 0,05 seperti yang telah disyaratkan. Dengan demikian dapat disimpulkan bahwa data dalam penelitian ini berdistribusi normal.

\section{Pengujian Model Regresi Secara Keseluruhan}

Tabel 2. Hasil Pengujian Model Regresi Secara Keseluruhan

\begin{tabular}{llrrrrr}
\hline \multicolumn{7}{c}{ ANOVA $^{\text {a }}$} \\
\hline \multirow{2}{*}{ Model } & $\begin{array}{l}\text { Sum of } \\
\text { Squares }\end{array}$ & Df & Mean Square & F & Sig. \\
\hline \multirow{3}{*}{1} & Regression & 584,839 & 1 & 584,839 & 15,659 &, $000^{\text {b }}$ \\
\cline { 2 - 7 } & Residual & 1008,778 & 27 & 37,362 & & \\
\cline { 2 - 7 } & Total & 1593,241 & 28 & & & \\
\hline
\end{tabular}

a. Dependent Variable: kompetensi professional

b. Predictors: (Constant), motivasi belajar

Sumber: Data Primer yang diolah SPSS 2019

Dari hasil analisis diatas dapat di ketahui nilai F-hitung untuk model regresi antara kompetensi professional guru dengan motivasi belajar siswa adalah sebesar 15,643 dengan nilai signifikansi sebesar 0,000 . Sementara nilai F-tabel pada tingkat kepercayaan $5 \%$ dan derajat bebas df $1=1$ dan df $2=27$ adalah sebesar 4,21 . Jika kedua nilai $\mathrm{F}$ ini dibandingkan dengan nilai $\mathrm{F}$-hitung yang diperoleh jauh lebih 
besar dari nilai F-tabel maka $\mathrm{H}_{0}$ ditolak. Dengan demikian dapat disimpulkan bahwa model regresi yang dibangun sesuai dengan data.

Pengujian hipotesis

Tabel 3. Hasil Pengujian Model Regresi Secara Parsial

\begin{tabular}{|c|c|c|c|c|c|}
\hline \multicolumn{6}{|c|}{ Coefficients $^{\mathrm{a}}$} \\
\hline \multirow[t]{2}{*}{ Model } & $\begin{array}{l}\text { Unstan } \\
\text { Coeff }\end{array}$ & $\begin{array}{l}\text { lardized } \\
\text { icients }\end{array}$ & $\begin{array}{l}\text { Standardized } \\
\text { Coefficients }\end{array}$ & $\mathrm{T}$ & Sig. \\
\hline & B & Std. Error & Beta & & \\
\hline (Constant) & 10,370 & 12,721 & & 815 & ,005 \\
\hline $\begin{array}{l}\text { Kompetensi } \\
\text { professional }\end{array}$ & ,785 & , 199 & ,606 & 3,955 & ,000 \\
\hline
\end{tabular}

a. Dependent Variable: Motivasi belajar

Sumber: Data Primer yang diolah SPSS 2019

Dari output diatas dapat dilihat nilai t-tabel yang diperoleh untuk variabel kompetensi professional guru adalah sebesar 3,955. Untuk mendapatkan kesimpulan apakah menerima atau menolak Ho, terlebih dahulu harus ditentukan nilai t-tabel yang akan digunakan. Dengan menggunakan tingkat signifikansi sebesar 5\% dan nilai df sebesar $n-k-1=29-1-1=27$ diperoleh nilai t-tabel sebesar 2.160. Jika dibandingkan dengan nilai t-hitung yang diperoleh sebesar 3,955 maka nilai t-hitung yang diperoleh masih lebih besar dari nilai t-tabel sehingga Ho ditolak. Dengan demikian pada tingkat kepercayaan 95\% dapat disimpulkan bahwa terdapat pengaruh yang positif dan signifikan dari kompetensi professional guru terhadapmotivasi belajar siswa.

Koefisien Determinasi

Tabel 4. Hasil Koefisien Determinasi

\begin{tabular}{lllrr}
\hline \multicolumn{4}{c}{ Model Summary $^{\mathbf{b}}$} \\
\hline Model & R & R Square & Adjusted R Square & $\begin{array}{c}\text { Std. Error } \\
\text { of the } \\
\text { Estimate }\end{array}$ \\
\hline 1 &, $606^{\mathrm{a}}$ &, 367 &, 343 & 6,112 \\
\hline
\end{tabular}

a. Predictors: (Constant), Kompetensi professional

b. Dependent Variable: Motivasi belajar

Sumber: Data Primer yang diolah SPSS 2019

Dari analisis di atas terlihat nilai koefisien determinasi dari model regresi yang telah diperoleh sebelumnya sebesar 0.367 Nilai ini berarti bahwa sebesar $36,7 \%$ variasi motivasi belajar siswa kelas VIII pada mata pelajaran IPS Terpadu 
di SMP Negeri 2 Telaga dijelaskan oleh kompetensi professional guru sedangkan sisanya 63,3\% dipengaruhi oleh variable lain. Dengan kata lain semakin baik kompetensi guru yang diterapkan maka motivasi belajar siswa juga akan semakin baik.

\section{A. Pembahasan}

Hasil analisis yang telah dilakukan pada pengujian nilai F-hitung untuk variabel kompetensi professional guru yang lebih besar dari $\mathrm{F}$-tabel sehingga $\mathrm{H}_{0}$ ditolak. Hal Ini menunjukkan bahwa pengaruh professional guru disekolah dapat meningkatkan motivasi belajar siswa.

Hasil pengujian normalitas sebesar 0,2 yang berada di atas 0,05 seperti yang telah disyaratkan. Dengan demikian dapat disimpulkan bahwa data dalam penelitian ini berdistribusi normal. Kesimpulan dari pengujian ini juga didukung dengan hasil plot data yang menunjukkan bahwa data dari variabel motivasi belajar siswa menyebar disekitar garis lurus.

Hasil penentuan kriteria uji regresi secara parsialDengan menggunakan tingkat signifikansi sebesar 5\% dan nilai df sebesar n-k-1=29-1-1 = 27 diperoleh nilai t-tabel sebesar 2.160. Jika dibandingkan dengan nilai t-hitung yang diperoleh sebesar 3,955 maka nilai t-hitung yang diperoleh masih lebih besar dari nilai t-tabel sehingga Ho ditolak. Dengan demikian pada tingkat kepercayaan 95\% dapat disimpulkan bahwa kompetensi professional guru memiliki pengaruh positif terhadap motivasi belajar.

Menurut Uno (2007: 18-19), kompetensi profesional guru adalah seperangkat kemampuan yang harus dimiliki oleh guru agar ia dapat melaksanakan tugas mengajar. Adapun kompetensi profesional mengajar yang harus dimiliki oleh seorang yaitu meliputi kemampuan dalam merencanakan, melaksanakan, dan mengevaluasi sistem pembelajaran, serta kemampuan dalam mengembangkan sistem pembelajaran. Sardiman (2011: 73) menyatakan bahwa "Motivasi Belajar Siswa merupakan keseluruhan daya penggerak di dalam diri siswa yang menimbulkan kegiatan belajar, yang menjamin kelangsungan dari kegiatan belajar, dan yang memberikan arah pada kegiatan belajar Hasil uji relibilitas pernyataan yang digunakan dalam penelitian ini telah memenuhi syarat reliabilitas yakni di atas 0.6. dengan demikian dapat disimpulkan bahwa pernyataan yang digunakan telah dapat dipahami baik oleh responden dan mampu menunjukkan konsistensi jawaban yang cukup baik pula.

Berdasarkan Penelitian yang dilakukan oleh Ayu Dwi Putri terdapat pengaruh professional guru terhadap motivasi belajar siswa dengan menggunakan korelasi product moment, sama halnya penelitian yang dilakukan oleh Hanian Manahen yang menggunakan proportionate stratified random sampling yang menyatakan bahwa kompetensi professional guru memilik pengaruh positif dan signifikan terhadap motivasi belajar.

Hasil pengujian hipotesis dengan menggunakan pengujian regresi linear sederhana, dari hasil perhitungan diperoleh persamaan regresi dan signifikan. hasil 
uji normalitas data baik variabel X (Kompetensi profesional guru) maupun variabel Y (Motivasi belajar) benar-benar berdistribusi normal.

Koefisien regresi yang bertanda positif dari variabel dukungan menunjukkan bahwakompetensi profesional guru akan meningkatkan motivasi belajar. Hal ini disebabkan dengan semakin baik kompetensi profesional guru akan membuat siswa lebih termotivasi untuk belajar di sekolah.

Berdasarkan penjelasan dan deskripsi hasil penelitian diatas maka pengaruh kompetensi profesional guru terhadap motivasi belajar siswa kelas VIII pada mata pelajaran IPS Terpadu di SMP Negeri 2 Telagadiperoleh nilai koefisien determinasi sebesar $36,7 \%$. Dengan demikian sisanya $63,3 \%$ dipengaruhi oleh variabel lain seperti kompetensi pedagogik, kompetensi kepribadian dan kompetensi sosial.

\section{KESIMPULAN}

Dari analisis yang telah dilakukan maka peneliti mengambil kesimpulan bahwa terdapat pengaruh yang positif dan signifikan kompetensi profesional guru terhadap motivasi belajar siswa. Semakin baik kompetensi professional guru maka semakin baik juga motivasi belajar siswa. Berdasarkan hasil uji normalitas data dan analisis regresi terdapat Pengaruh kompetensi professional guru terhadap motivasi belajar siswa mencapai 36,7,\% sedangkan sisanya sebesar 63,3\% dipengaruhi oleh faktor-faktor di luar kompetensi profesional guru yang diteliti.

\section{DAFTAR PUSTAKA}

Annurahman, 2009.Metodologi Penelitian. Jakarta: Ciputat Pres.

Dimiyanti. 1999. Belajar Dan Pembelajaran. Jakarta: Rineka Cipta.

Hamalik.2012. Psikologi Belajar dan Mengajar. Bandung: Sinar Baru

Algensindo.Irham, Muhamad \& Wiyani, Novan Ardy. 2013. Psikologi Pendidikan. Jogjakarta: Ar-Ruzz Media.

Mulyasa, E. 2007. Standar Kompetensi dan Sertifikasi Guru. Bandung: PT Remaja Rosdakarya.

Sangadji, Etta Mamang dan Sopiah. 2010. Metodologi Penelitian. ANDI. Yogyakarta.

Sardiman. A. M. 2011. Interaksi dan Motivasi Belajar Mengajar. Jakarta: PT RajaGrafindo Persada.

Slameto. 2010. Belajar dan Faktor-Faktor yang Mempengaruhinya. Jakarta: Rineka Cipta.

Sugiyono. 2015. Metode Penelitian, Kuantitatif. Kualitatif dan $R \& D$. Bandung: Ganesha.

Sugiyono. 2017. Metode Penelitian (Kuantitatif, Kualitatif, R\&D). Alfabeta, Bandung.

Sugihartono, dkk. 2013. Psikologi Pendidikan. Yoggyakarta: UNY Press. 
Undang-Undang Republik Indonesia Nomor 14 Tahun 2005 tentang Guru dan Dosen. Bandung: Citra Umbara.

.Uno. Hamzah B. 2007. Standar kompetensi guru dan dosen. Jakarta: PT Bumi Aksara.

Uno. Hamzah B. 2013. Teori Motivasi dan Pengukurannya. Jakarta: PT Bumi Aksara.

Uzer, Moch. Usman. 2009. Menjadi Guru Profesional. Bandung: PT Remaja Rosdakarya 